\title{
Enhanced Bromate Formation during Chlorination of Bromide- Containing Waters in the Presence of CuO: Catalytic Disproportionation of Hypobromous Acid
}

\author{
Chao Liu, ${ }^{\dagger}$ Urs von Gunten, ${ }^{\ddagger}, \S$ and Jean-Philippe Croué ${ }^{*} \dagger$ \\ ${ }^{\dagger}$ Water Desalination and Reuse Center, King Abdullah University of Science and Technology (KAUST), Thuwal 23955-6900, Saudi \\ Arabia \\ ${ }^{\ddagger}$ Eawag, Swiss Federal Institute of Aquatic Science and Technology, Ueberlandstrasse 133, CH-8600 Dübendorf, Switzerland \\ ${ }^{\S}$ School of Architecture, Civil and Environmental Engineering (ENAC), Ecole Polytechnique Fédérale de Lausanne (EPFL), \\ CH-1015 Lausanne, Switzerland
}

\section{Supporting Information}

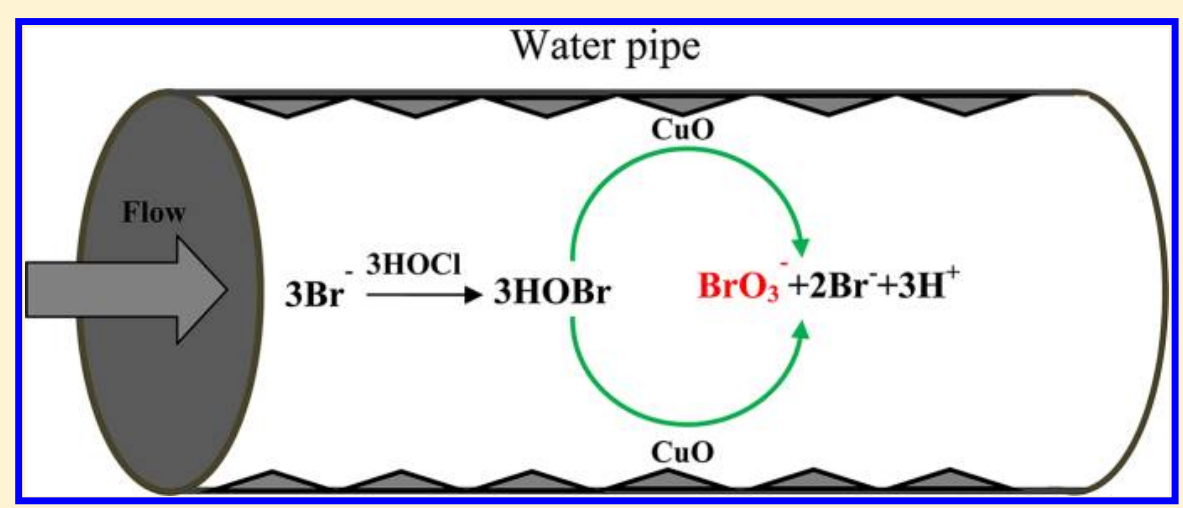

ABSTRACT: Bromate $\left(\mathrm{BrO}_{3}^{-}\right)$in drinking water is traditionally seen as an ozonation byproduct from the oxidation of bromide $\left(\mathrm{Br}^{-}\right)$, and its formation during chlorination is usually not significant. This study shows enhanced bromate formation during chlorination of bromide-containing waters in the presence of cupric oxide $(\mathrm{CuO}) . \mathrm{CuO}$ was effective to catalyze hypochlorous acid $(\mathrm{HOCl})$ or hypobromous acid $(\mathrm{HOBr})$ decay (e.g., at least $10^{4}$ times enhancement for $\mathrm{HOBr}$ at $\mathrm{pH} 8.6$ by $0.2 \mathrm{~g} \mathrm{~L}^{-1} \mathrm{CuO}$ ). Significant halate concentrations were formed from a $\mathrm{CuO}$-catalyzed hypohalite disproportionation pathway. For example, the chlorate concentration was $2.7 \pm 0.2 \mu \mathrm{M}\left(225.5 \pm 16.7 \mu \mathrm{g} \mathrm{L}^{-1}\right)$ after $90 \min$ for $\mathrm{HOCl}\left(C_{\mathrm{o}}=37 \mu \mathrm{M}, 2.6 \mathrm{mg} \mathrm{L}^{-1} \mathrm{Cl}_{2}\right)$ in the presence of $0.2 \mathrm{~g} \mathrm{~L}^{-1} \mathrm{CuO}$ at $\mathrm{pH} 7.6$, and the bromate concentration was $6.6 \pm 0.5 \mu \mathrm{M}\left(844.8 \pm 64 \mu \mathrm{g} \mathrm{L}^{-1}\right)$ after 180 min for $\operatorname{HOBr}\left(C_{\mathrm{o}}=35 \mu \mathrm{M}\right)$ in the presence of $0.2 \mathrm{~g} \mathrm{~L}^{-1} \mathrm{CuO}$ at $\mathrm{pH}$ 8.6. The maximum halate formation was at $\mathrm{pHs} 7.6$ and 8.6 for $\mathrm{HOCl}$ or $\mathrm{HOBr}$, respectively, which are close to their corresponding $\mathrm{p} K_{\mathrm{a}}$ values. In a $\mathrm{HOCl}-\mathrm{Br}^{-}-\mathrm{CuO}$ system, $\mathrm{BrO}_{3}{ }^{-}$formation increases with increasing $\mathrm{CuO}$ doses and initial $\mathrm{HOCl}$ and $\mathrm{Br}^{-}$concentrations. A molar conversion $\left(\mathrm{Br}^{-}\right.$to $\left.\mathrm{BrO}_{3}^{-}\right)$of up to $(90$ $\pm 1) \%$ could be achieved in the $\mathrm{HOCl}-\mathrm{Br}^{-}-\mathrm{CuO}$ system because of recycling of $\mathrm{Br}^{-}$to $\mathrm{HOBr}$ by $\mathrm{HOCl}$, whereas the maximum $\mathrm{BrO}_{3}{ }^{-}$yield in $\mathrm{HOBr}-\mathrm{CuO}$ is only $26 \%$. Bromate formation is initiated by the formation of a complex between $\mathrm{CuO}$ and $\mathrm{HOBr} /$ $\mathrm{OBr}^{-}$, which then reacts with $\mathrm{HOBr}$ to generate bromite. Bromite is further oxidized to $\mathrm{BrO}_{3}^{-}$by a second CuO-catalyzed process. These novel findings may have implications for bromate formation during chlorination of bromide-containing drinking waters in copper pipes.

\section{INTRODUCTION}

The formation of bromate during the ozonation of bromidecontaining waters has been intensively studied. ${ }^{1-5}$ In the presence of ozone, bromate is produced from the reactions of ozone and $\cdot \mathrm{OH}$ radicals with bromide $\left(\mathrm{Br}^{-}\right)$, via several intermediates including hypobromite $\left(\mathrm{BrO}^{-}\right)$and bromite $\left(\mathrm{BrO}_{2}^{-}\right) .^{5}$ Because bromate is potentially carcinogenic, it is regulated in potable water at a maximum contaminant level (MCL) of $10 \mu \mathrm{g} \mathrm{L}^{-1}$ in many countries. ${ }^{6-8}$ Moreover, bromate is stable, and there is currently no economically feasible technology to remove it once it is formed. ${ }^{9}$ Therefore, the treatment conditions have to be optimized in some cases to mitigate bromate formation while disinfection is still guaranteed (e.g., ammonia addition and lowering the $\mathrm{pH}^{9}$ ).

Due to its low cost, chlorine is globally the most used drinking water disinfectant. It is commonly used as a final treatment step to maintain a residual disinfectant in distribution

Received: May 31, 2012

Revised: $\quad$ September 8, 2012

Accepted: September 10, 2012

Published: September 10, 2012 
systems. Bromate can be a byproduct of commercial solutions of sodium hypochlorite. ${ }^{10}$ In a survey, it has been demonstrated that a few micrograms per liter of bromate can be found in distributed waters if such products are used for final disinfection. Nevertheless, bromate formation is generally not of concern in drinking water chlorination. ${ }^{11}$ Significant bromate formation in chlorinated water can be observed under some special conditions (e.g., sunlight irradiation). ${ }^{12}$

Bromate formation during chlorination of bromide-containing waters is a slow process. In a first step (eqs 1 and 2), bromide is oxidized by hypochlorous acid ( $\mathrm{HOCl}$ ) to form hypobromous acid ( $\mathrm{HOBr}){ }^{13}$ which is in equilibrium with $\mathrm{OBr}^{-}$with a $\mathrm{pK}_{\mathrm{a}}$ of $8.8 .^{1}$

$$
\begin{aligned}
& \mathrm{HOCl}+\mathrm{Br}^{-} \rightarrow \mathrm{HOBr}+\mathrm{Cl}^{-} \\
& k=1.55 \times 10^{3} \mathrm{M}^{-1} \mathrm{~s}^{-1}\left(25^{\circ} \mathrm{C}\right) \\
& \mathrm{OCl}^{-}+\mathrm{Br}^{-} \rightarrow \mathrm{OBr}^{-}+\mathrm{Cl}^{-} \\
& k=9 \times 10^{-4} \mathrm{M}^{-1} \mathrm{~s}^{-1}\left(25^{\circ} \mathrm{C}\right)
\end{aligned}
$$

Although there is no further reaction between $\mathrm{HOCl} / \mathrm{OCl}^{-}$ and $\mathrm{HOBr} / \mathrm{OBr}^{-},{ }^{14} \mathrm{HOBr}$ can disproportionate to bromate and bromide (eqs 3-5). ${ }^{15,16}$ The disproportionation of $\mathrm{HOBr}$ is the reaction in which $\mathrm{HOBr}$ (i.e., $\mathrm{Br}(+\mathrm{I})$ ) reacts with itself, leading to a reduced species $\left(\mathrm{Br}^{-}, \mathrm{Br}(-\mathrm{I})\right)$ and to oxidized species $\left(\mathrm{BrO}_{2}{ }^{-}, \mathrm{Br}(+\mathrm{III}), \mathrm{BrO}_{3}{ }^{-}, \mathrm{Br}(+\mathrm{V})\right)$.

$$
\begin{aligned}
& \mathrm{HOBr}+\mathrm{HOBr} \rightarrow \mathrm{BrO}_{2}^{-}+\mathrm{Br}^{-}+2 \mathrm{H}^{+} \\
& k=2 \times 10^{-3} \mathrm{M}^{-1} \mathrm{~s}^{-1}\left(25^{\circ} \mathrm{C}\right) \\
& \mathrm{OBr}^{-}+\mathrm{OBr}^{-} \rightarrow \mathrm{BrO}_{2}^{-}+\mathrm{Br}^{-} \\
& \quad k=6 \times 10^{-7} \mathrm{M}^{-1} \mathrm{~s}^{-1}\left(25^{\circ} \mathrm{C}\right) \\
& \mathrm{HOBr}+\mathrm{BrO}_{2}^{-} \rightarrow \mathrm{BrO}_{3}^{-}+\mathrm{Br}^{-}+\mathrm{H}^{+} \\
& \quad k=1.8 \times 10^{-2} \mathrm{M}^{-1} \mathrm{~s}^{-1}\left(\mathrm{pH}=8.84,25^{\circ} \mathrm{C}\right)
\end{aligned}
$$

The low rate constants for $\mathrm{HOBr}$ disproportionation illustrate that the formation of bromate during chlorination is a very slow process in homogeneous solution and should not lead to significant bromate levels in distribution systems.

Recently, we discovered that bromate formation can be significant in distribution systems employing chlorine as a final disinfectant. The unexpected increase of the bromate content was attributed to the presence of cupric oxide $(\mathrm{CuO})$ accumulated on the surface of the pipes. ${ }^{17}$

Previous studies indicated that metal oxides (e.g., $\mathrm{CuO}){ }^{18-20}$ $\mathrm{Cu}(\mathrm{II})$ in alkaline solutions, ${ }^{21,22}$ and $\mathrm{Cu}(\mathrm{OH})_{2}{ }^{23}$ can enhance $\mathrm{HOCl} / \mathrm{OCl}^{-}$decay. A similar enhancement for $\mathrm{HOBr} / \mathrm{OBr}^{-}$ decay in alkaline solution by $\mathrm{Cu}(\mathrm{II})$ was also confirmed. ${ }^{21}$ However, the reported products of the metal (oxides)-catalyzed decomposition of hypohalite are oxygen and the halide. Hypochlorite decay in the presence of manganese, iron, cobalt, nickel, and copper oxides did not lead to enhanced chlorate formation. ${ }^{19}$

In view of our observation of enhanced bromate formation in water pipes and the potential toxicological significance of bromate production in distribution systems (e.g., in household copper pipes), the aim of this study was to elucidate the role of $\mathrm{CuO}$ in the enhancement of bromate formation during chlorination of bromide-containing waters. The influence of drinking water treatment parameters such as chlorine dose, bromide concentration, and $\mathrm{pH}$ in the presence of various concentrations of $\mathrm{CuO}$ on the kinetics and extent of bromate formation was investigated.

\section{MATERIALS AND METHODS}

Reagents. All chemical solutions were prepared from reagent grade chemicals or stock solutions using deionized water $(18.2 \mathrm{M} \Omega \cdot \mathrm{cm}$, Milli-Q Millipore). A sodium hypochlorite $(\mathrm{NaOCl})$ solution was used as the source of chlorine $(13 \%$ active chlorine, Acros Organics). For experiments investigating chlorate formation, chlorate-free $\mathrm{NaOCl}$ solution was produced by bubbling chlorine gas (99.999\% pure, Abdullah Hashim Industrial Gases and Equipments Co. Ltd., Jeddah, KSA) through continuously stirred $0.1 \mathrm{M}$ sodium hydroxide at $4{ }^{\circ} \mathrm{C}$. $\mathrm{HOBr}$ solutions were prepared by reacting $\mathrm{NaOCl}$ with $\mathrm{Br}^{-}$ according to Lei et al. ${ }^{24} \mathrm{CuO}$ particles were prepared in our laboratory, and their surface area, i.e., $18.1 \mathrm{~m}^{2} \mathrm{~g}^{-1}$, was analyzed by a Micromeritics Tristar II surface area and porosity system. Details for the preparation of $\mathrm{HOBr}$ solutions and $\mathrm{CuO}$ particles are given in the Supporting Information (Text 1 in SI).

The $\mathrm{pH}_{\mathrm{pzc}}$ ( $\mathrm{pH}$ at which the surface has a zero charge) of the $\mathrm{CuO}$ particles was determined by a potentiometric titration in $0.01 \mathrm{M} \mathrm{NaNO}_{3}$ solutions under a nitrogen atmosphere with $0.02 \mathrm{M} \mathrm{HCl}$ and $0.02 \mathrm{M} \mathrm{NaOH}^{25}$ The intrinsic surface acidity constants, i.e., $\mathrm{p} K_{\mathrm{a} 1}($ int $)=7.1$ and $\mathrm{p} K_{\mathrm{a} 2}($ int $)=10.1$ (eq 6), were determined from the titration data. The obtained $\mathrm{pH}_{\mathrm{pzc}}$ is 8.6.

$$
\equiv \mathrm{Cu}-\mathrm{OH}_{2}+\underset{\mathrm{p} K_{\mathrm{a} 1}}{\stackrel{-\mathrm{H}^{+}}{\rightleftarrows}} \equiv \mathrm{Cu}-\mathrm{OH} \underset{\mathrm{pK}_{\mathrm{a} 2}}{\stackrel{-\mathrm{H}^{+}}{\rightleftarrows}} \equiv \mathrm{Cu}-\mathrm{O}^{-}
$$

Analytical Methods. Residual oxidant stands for the sum of $[\mathrm{HOCl}]_{\mathrm{T}}$ and $[\mathrm{HOBr}]_{\mathrm{T}}$ (where $[\mathrm{HOX}]_{\mathrm{T}}=[\mathrm{HOX}]+$ $\left[\mathrm{OX}^{-}\right] ; \mathrm{X}=\mathrm{Cl}, \mathrm{Br}$; and $[\mathrm{HOX}]_{\mathrm{TO}}$ is the initial concentration of HOX). Oxidant concentrations were analyzed spectrophotometrically by the $N, N$-diethyl- $p$-phenylenediamine (DPD) method at $515 \mathrm{~nm}^{26}$

Bromate, chlorite, and chlorate were quantified by a Dionex 1600 reagent free ion chromatograph (IC) with a $\mathrm{KOH}$ online eluent generator. Samples, injected via a $250 \mu \mathrm{L}$ loop, were eluted $(20 \mathrm{mM} \mathrm{KOH})$ at a flow rate of $0.25 \mathrm{~mL} \mathrm{~min}^{-1}$ through an Ionpac AS19 column. The quantification limits for bromate, chlorite, and chlorate are $1 \mu \mathrm{g} \mathrm{L}^{-1}$, and relative standard deviations are below 5\%. Retention times for chlorite, bromate, and chlorate are 6.5, 7.0, and $10.5 \mathrm{~min}$, respectively.

The dissolved copper content was determined on an Agilent 7500 inductively coupled plasma mass spectrometer (ICP-MS) with a detection limit of $0.01 \mu \mathrm{g} \mathrm{L}^{-1}$.

Experimental Setup. The role of several parameters in the kinetics of bromate formation was investigated $(\mathrm{CuO}$ dose, initial concentrations of $\mathrm{HOCl}$ and bromide, and $\mathrm{pH}$ ). Table S1 (SI) gives the details of the experimental conditions. The $\mathrm{CuO}$ dose ranged from 0.05 to $0.5 \mathrm{~g} \mathrm{~L}^{-1}$. The initial concentrations ranged from 14 to $70 \mu \mathrm{M}$ (i.e., $1.0-5.0 \mathrm{mg} \mathrm{L}^{-1}$ of $\mathrm{Cl}_{2}$ ) for $\mathrm{HOCl}$ or $\mathrm{HOBr}$ and from 2 to $10 \mu \mathrm{M}$ for bromide (i.e., 160$\left.800 \mu \mathrm{g} \mathrm{L}^{-1}\right)$. The $\mathrm{pHs}$ were adjusted to $6.6,7.6,8.6,9.6$, and 10.6 with $2.5 \mathrm{mM}$ tetraborate buffer and acid or base. No significant $\mathrm{pH}$ change was observed during the reaction for the solutions buffered at $\mathrm{pHs} 8.6,9.6$, and 10.6. The changes were less than 0.2 for the pHs 6.6 and 7.6.

All experiments were conducted in the dark and under continuous agitation using a magnetic stirrer. Reactions were initiated by the injection of a $\mathrm{HOCl}$ or $\mathrm{HOBr}$ stock solution to the tetraborate buffered solutions containing $\mathrm{CuO}$ at room temperature $\left(21 \pm 1^{\circ} \mathrm{C}\right)$. Bromide was added when required. 
Samples were withdrawn at preselected time intervals and filtered within $15 \mathrm{~s}$ (insignificant considering the reaction times of several hours) through a $0.45 \mu \mathrm{m}$ syringe filter (surfactantfree cellulose acetate membrane). The filter was pretreated with $\mathrm{HOCl}$ or $\mathrm{HOBr}$ solutions $\left(2.5 \mathrm{mg} \mathrm{L}^{-1} \mathrm{Cl}_{2}\right)$ and then rinsed with MQ water. Thus, the filtration had no significant oxidant demand. The filtered samples were analyzed for residual oxidant concentrations. For IC analyses, the samples were quenched immediately with sulfite.

\section{RESULTS AND DISCUSSION}

Chlorate Formation from $\mathrm{HOCl}$ Decay in the Presence of $\mathrm{CuO}$. In the absence of metal oxides, the depletion of $\mathrm{HOCl}$ mainly occurs through slow disproportionation (eq 7), ${ }^{27}$ and oxygen generation (eq 8) is minor (less than $10 \%) .^{22,28}$

$$
\begin{aligned}
& 2 \mathrm{HOCl}+\mathrm{OCl}^{-} \rightarrow 2 \mathrm{Cl}^{-}+\mathrm{ClO}_{3}^{-}+2 \mathrm{H}^{+} \\
& k=1.25 \times 10^{-2} \mathrm{M}^{-2} \mathrm{~s}^{-1}\left(25^{\circ} \mathrm{C}\right) \\
& 2 \mathrm{HOCl} \rightarrow 2 \mathrm{Cl}^{-}+\mathrm{O}_{2}+2 \mathrm{H}^{+}
\end{aligned}
$$

However, in the presence of $\mathrm{CuO}$, the formation of $\mathrm{O}_{2}$ (eq 9) predominates during the $\mathrm{HOCl}$ decay. ${ }^{19}$

$$
2 \mathrm{HOCl} \stackrel{\mathrm{CuO}}{\longrightarrow} 2 \mathrm{Cl}^{-}+\mathrm{O}_{2}+2 \mathrm{H}^{+} \quad k_{\mathrm{ClO}}
$$

$\mathrm{By}$ analogy, the $\mathrm{CuO}$-catalyzed disproportionation of $\mathrm{HOCl}$ can be described as eq 10 (where $\mathrm{Cl}(\mathrm{I})$ : $\mathrm{HOCl}$ or $\mathrm{OCl}^{-}, \mathrm{Cl}(-\mathrm{I}$ ): $\mathrm{Cl}^{-}, \mathrm{Cl}(\mathrm{V}): \mathrm{ClO}_{3}^{-}$)

$$
3 \mathrm{Cl}(\mathrm{I}) \stackrel{\mathrm{CuO}}{\longrightarrow} 2 \mathrm{Cl}(-\mathrm{I})+\mathrm{Cl}(\mathrm{V}) \quad k_{\mathrm{ClP}}
$$

$k_{\mathrm{Cl}}=k_{\mathrm{ClO}}+k_{\mathrm{ClP}}$ is the total apparent $\mathrm{HOCl}$ decay rate constant if pseudo-first-order kinetics are assumed for both processes (see below).

Figure 1 shows the $\mathrm{HOCl}$ decay and chlorate formation in the presence of $\mathrm{CuO}$ for varying $\mathrm{pH}$ values. According to the rate constant of eq 7 , the loss of chlorine in homogeneous solution would be less than $1 \%$ for a reaction time of $180 \mathrm{~min}$. In agreement with previous studies, significant chlorine depletion was observed at all $\mathrm{pH}$ values in the presence of CuO. ${ }^{18,20}$ The chlorine decay rates decrease as the $\mathrm{pH}$ increases from 6.6 to 9.6. Applying pseudo-first-order kinetics to fit the $\mathrm{HOCl}$ decay, the corresponding pseudo-first-order rate constants $\left(k_{\mathrm{Cl}}\right)$ were $(4.0 \pm 0.1) \times 10^{-4} \mathrm{~s}^{-1},(3.5 \pm 0.1) \times$ $10^{-4} \mathrm{~s}^{-1},(1.0 \pm 0.1) \times 10^{-4} \mathrm{~s}^{-1}$, and $(3.2 \pm 0.1) \times 10^{-5} \mathrm{~s}^{-1}$ for $\mathrm{pH}$ 6.6, 7.6, 8.6, and 9.6, respectively (Figure S1A, Table S1, $\mathrm{SI}$ ), which is significantly enhanced compared to homogeneous reactions. For instance, the first-order rate constant in the absence of $\mathrm{CuO}$ can be calculated as $1.7 \times 10^{-12} \mathrm{~s}^{-1}$ (using $[\mathrm{HOCl}]_{\mathrm{TO}}=3.7 \times 10^{-5} \mathrm{M}$, and a third-order rate constant of $1.25 \times 10^{-2} \mathrm{M}^{-2} \mathrm{~s}^{-1}$ at $\mathrm{pH}=7.3^{27}$ ). At $\mathrm{pH} 7.6$, this rate constant will be even lower. ${ }^{27}$ Therefore, the decay rate of $\mathrm{HOCl}$ was enhanced about $10^{8}$ times at $\mathrm{pH} 7.6$ in the presence of $0.2 \mathrm{~g} \mathrm{~L}^{-1} \mathrm{CuO}$.

Figure 1B shows significant chlorate formation, except at $\mathrm{pH}$ 9.6, indicating that chlorate can be formed via a $\mathrm{CuO}$-catalyzed disproportionation reaction. Concomitant to the fast chlorine decay, chlorate concentrations at $\mathrm{pH} 6.6$ and 7.6 increase quickly within the first $60 \mathrm{~min}$ and then reach a plateau. At $\mathrm{pH}$ 8.6 , only a limited chlorate formation was observed up to 30 min due to the small chlorine depletion. After $30 \mathrm{~min}$, the increase of chlorate is concomitant to the chlorine decay. Only traces of chlorate were detected at $\mathrm{pH}$ 9.6.

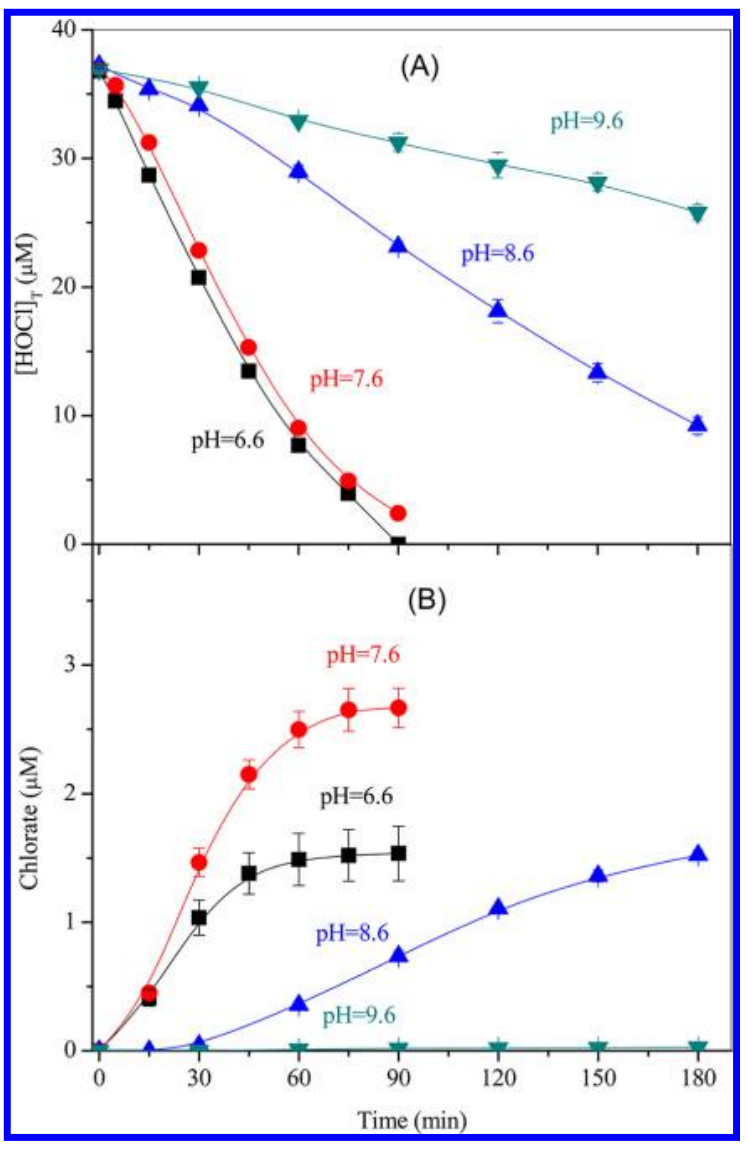

Figure 1. $\mathrm{HOCl}$ decay (A) and chlorate formation (B) for varying $\mathrm{pH}$ (2.5 mM tetraborate buffer). Experimental conditions: $T=21{ }^{\circ} \mathrm{C}$, $[\mathrm{CuO}]=0.2 \mathrm{~g} \mathrm{~L}^{-1},[\mathrm{HOCl}]_{\mathrm{To}}=37 \mu \mathrm{M}\left(2.6 \mathrm{mg} \mathrm{L}^{-1} \mathrm{Cl}_{2}\right)$.

Chlorite is a possible intermediate in chlorate formation. However, chlorite concentrations were insignificant (below $0.02 \mu \mathrm{M}$ ), which is in agreement with studies performed in the absence of $\mathrm{CuO}{ }^{27,28}$ Furthermore, the adsorption of chlorate on $\mathrm{CuO}$ is insignificant (Figure S2, SI). A plot of $3 \Delta \mathrm{ClO}_{3}{ }^{-}$vs $\Delta \mathrm{HOCl}$ (the stoichiometry for chlorate formation, eq 10) at different reaction times showed a good linear correlation (Figure S1B, SI). The fitted slopes (i.e., fractions of chlorate formation over the total $\mathrm{HOCl}$ decay) are $(18 \pm 1) \%,(27 \pm$ $1) \%$, $(17 \pm 1) \%$, and $1 \%$ for $\mathrm{pHs} 6.6,7.6,8.6$, and 9.6, respectively. These fractions are significantly below $100 \%$, demonstrating that chlorate formation (eq 10) is a minor pathway for $\mathrm{HOCl}$ decay. The $k_{\mathrm{ClP}}$ values obtained by multiplying the fractions with $k_{\mathrm{Cl}}$ are $(7.2 \pm 0.2) \times 10^{-5} \mathrm{~s}^{-1}$, $(9.5 \pm 0.3) \times 10^{-5} \mathrm{~s}^{-1},(1.7 \pm 0.2) \times 10^{-5} \mathrm{~s}^{-1}$, and $4 \times 10^{-7} \mathrm{~s}^{-1}$ for $\mathrm{pH}$ 6.6, 7.6, 8.6, and 9.6, respectively.

The $\mathrm{pH}$ effect on $k_{\mathrm{ClP}}, k_{\mathrm{ClO}}$, and the chlorate yield $\left(\Delta \mathrm{ClO}_{3}{ }^{-}\right.$ vs $\Delta \mathrm{HOCl}$, i.e., one-third of the slopes in Figure $\mathrm{S} 1 \mathrm{~B}, \mathrm{SI})$ is illustrated in Figure 2. $k_{\mathrm{ClO}}$ increases with decreasing $\mathrm{pH}$, which agrees with observations in the absence of $\mathrm{CuO} .{ }^{28}$ This trend may indicate that the reaction to oxygen occurs between two $\mathrm{HOCl}$ molecules. The maximum of $k_{\mathrm{ClP}}$ value is observed at $\mathrm{pH}$ 7.6, close to the $\mathrm{pK} K_{\mathrm{a}}$ of $\mathrm{HOCl}$. This may indicate that the disproportionation in the presence of $\mathrm{CuO}$ occurs via an interaction between $\mathrm{HOCl}$ and $\mathrm{OCl}^{-}$.

Figure 2 also shows the observed chlorate yield as a function of $\mathrm{pH}$. The decrease in chlorate yield from $\mathrm{pH} 7.6$ to 9.6 follows the reduction of the $k_{\mathrm{ClP}}$ value. However, chlorate formation is not only controlled by $k_{\mathrm{ClP}}$ but also affected by 


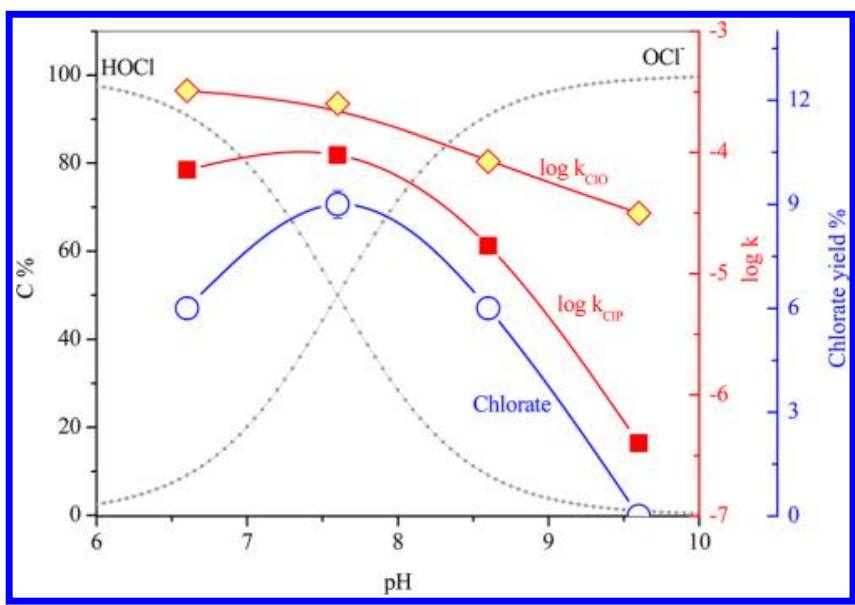

Figure 2. Influence of $\mathrm{pH}$ on speciation of $\mathrm{HOCl}$, rate constants for oxygen formation $\left(k_{\mathrm{ClO}}\right)$ and disproportionation $\left(k_{\mathrm{CIP}}\right)$, and chlorate yield. Experimental conditions: $T=21{ }^{\circ} \mathrm{C},[\mathrm{CuO}]=0.2 \mathrm{~g} \mathrm{~L}^{-1}$, $[\mathrm{HOCl}]_{\mathrm{To}}=37 \mu \mathrm{M}\left(2.6 \mathrm{mg} \mathrm{L}^{-1} \mathrm{Cl}_{2}\right)$. For $\mathrm{pHs} 6.6$ and 7.6 , reaction times are $90 \mathrm{~min}$, while for $\mathrm{pHs} 8.6$ and 9.6, reaction times are 180 min.

$k_{\mathrm{ClO}}$, which contributes significantly to the $\mathrm{HOCl}$ decay. At $\mathrm{pH}$ 6.6, the highest $k_{\mathrm{ClO}}$ value leads to less residual $\mathrm{HOCl}$ available for disproportionation, which tends to decrease the chlorate yield. In contrast to our findings, chlorate was not detected during $\mathrm{HOCl}$ decomposition using various $\mathrm{Cu}(\mathrm{II})$ species in previous studies ${ }^{18,19,21,22}$ because the previous experiments were conducted under basic conditions. From our data, it remains unclear which $\mathrm{CuO}$ species is mainly involved in catalysis of $\mathrm{HOCl}$ decay and chlorate formation.

Bromate Formation from $\mathrm{HOBr}$ Decay in the Presence of CuO. Similarly to $\mathrm{HOCl}$, the disproportionation of $\mathrm{HOBr}$ in the presence of $\mathrm{CuO}$ can be formulated by eq 11

$$
3 \mathrm{Br}(\mathrm{I}) \stackrel{\mathrm{CuO}}{\longrightarrow} 2 \mathrm{Br}(-\mathrm{I})+\mathrm{Br}(\mathrm{V}) \quad k_{\mathrm{BrP}}
$$

If we consider the $\mathrm{CuO}$-catalyzed decomposition of $\mathrm{HOBr}$ to bromide and $\mathrm{O}_{2}$, the reaction can be formulated as eq 12 .

$$
2 \mathrm{HOBr} \stackrel{\mathrm{CuO}}{\longrightarrow} 2 \mathrm{Br}^{-}+\mathrm{O}_{2}+2 \mathrm{H}^{+} \quad k_{\mathrm{BrO}}
$$

$k_{\mathrm{Br}}=k_{\mathrm{BrP}}+k_{\mathrm{BrO}}$ is the total apparent $\mathrm{HOBr}$ decay rate constant if pseudo-first-order kinetics are assumed for both processes (see below).

Figure 3 shows the $\mathrm{HOBr}$ decay and bromate formation in the presence of $\mathrm{CuO}$ for various $\mathrm{pH}$ conditions. According to the rate constants listed in eqs 3-5, the $\mathrm{HOBr}$ decay in homogeneous solution is very slow for our experimental conditions $\left([\mathrm{HOBr}]_{\mathrm{TO}}=35 \mu \mathrm{M}\right)$. For instance, at $\mathrm{pH} 8.8$ in the absence of $\mathrm{CuO}, k_{\mathrm{Br}}$ was reported to be $2 \times 10^{-4} \mathrm{M}^{-1} \mathrm{~s}^{-1}$, equivalent to a first-order rate constant of $7 \times 10^{-9} \mathrm{~s}^{-1}$. The decomposition of $\mathrm{HOBr}$ is enhanced in the presence of $\mathrm{CuO}$ at any $\mathrm{pH}$ ranging from 6.6 to 10.6 . Figure $\mathrm{S} 3 \mathrm{~A}$ (SI) indicates that the $\mathrm{HOBr}$ decay follows pseudo-first-order kinetics with $k_{\mathrm{Br}}$ values of $(4.5 \pm 0.3) \times 10^{-5} \mathrm{~s}^{-1},(8.7 \pm 0.3) \times 10^{-5} \mathrm{~s}^{-1},(1.5 \pm$ $0.1) \times 10^{-4} \mathrm{~s}^{-1},(1.7 \pm 0.1) \times 10^{-4} \mathrm{~s}^{-1}$, and $(1.7 \pm 0.1) \times 10^{-4}$ $\mathrm{s}^{-1}$ for $\mathrm{pH}$ 6.6, 7.6, 8.6, 9.6, and 10.6, respectively. Therefore, the $\mathrm{HOBr}$ decay rate is enhanced by more than $4-5$ orders of magnitude in the presence of $\mathrm{CuO}$.

Figure $3 \mathrm{~B}$ indicates that significant concentrations of bromate were formed in the presence of $\mathrm{CuO}$ from the disproportionation of $\mathrm{HOBr}$ under various $\mathrm{pH}$ conditions. Bromate concentrations increase slowly within the first $15 \mathrm{~min}$,

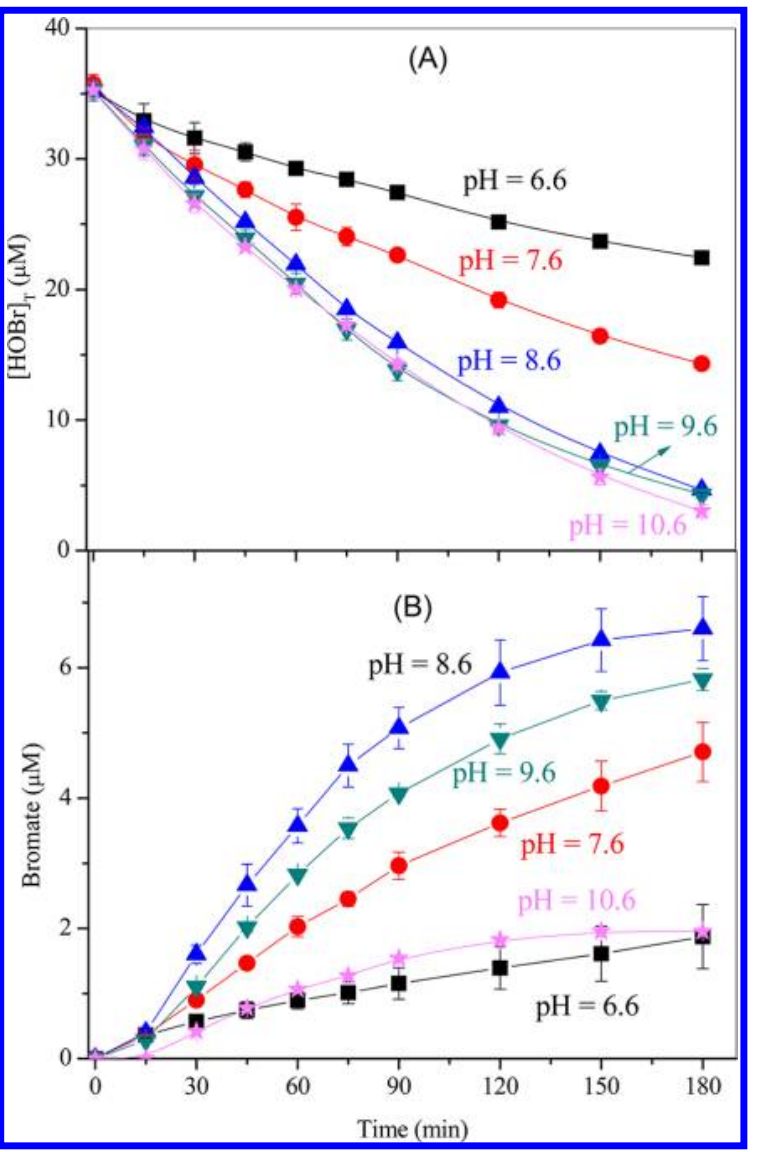

Figure 3. $\mathrm{HOBr}$ decay (A) and bromate formation (B) for varying $\mathrm{pH}$ (2.5 mM tetraborate buffer). Experimental conditions: $T=21{ }^{\circ} \mathrm{C}$, $[\mathrm{CuO}]=0.2 \mathrm{~g} \mathrm{~L}^{-1},[\mathrm{HOBr}]_{\mathrm{To}}=35 \mu \mathrm{M}$.

implying that a build-up of an intermediate, probably bromite, is necessary before bromate is formed. ${ }^{15}$ After $15 \mathrm{~min}$ the concentration of bromate started to increase until most of the $\mathrm{HOBr}$ was depleted.

There is no significant adsorption of bromate on $\mathrm{CuO}$, hence the formed bromate is released to the aqueous solution (Figure $\mathrm{S} 2, \mathrm{SI})$. Similarly to $\mathrm{HOCl}$, the slopes $\left(3 \Delta \mathrm{BrO}_{3}{ }^{-} / \Delta \mathrm{HOBr}\right)$ did not vary significantly with reaction time, except within the initial reaction stage, probably because of the build-up of $\mathrm{BrO}_{2}{ }^{-}$ (Figure S3B, SI). The fractions of decayed $\mathrm{HOBr}$ that lead to bromate (i.e., fitted slopes) are $(43 \pm 1) \%,(64 \pm 1) \%,(77 \pm$ $2) \%$, $(56 \pm 1) \%$, and $(21 \pm 1) \%$ for $\mathrm{pH} 6.6,7.6,8.6,9.6$, and 10.6, respectively. Again, the fractions are less than $100 \%$, indicating that reaction 12 is important. On the basis of this, $k_{\mathrm{BrP}}$ values calculated by multiplying the fractions that lead to bromate with $k_{\mathrm{Br}}$ are $(1.9 \pm 0.1) \times 10^{-5} \mathrm{~s}^{-1},(5.6 \pm 0.2) \times 10^{-5}$ $\mathrm{s}^{-1},(1.2 \pm 0.1) \times 10^{-4} \mathrm{~s}^{-1},(1.0 \pm 0.1) \times 10^{-4} \mathrm{~s}^{-1}$, and $(3.6 \pm$ $0.2) \times 10^{-5} \mathrm{~s}^{-1}$ for $\mathrm{pHs} 6.6,7.6,8.6,9.6$, and 10.6, respectively.

The influence of $\mathrm{pH}$ on the distribution of $\mathrm{HOBr}, k_{\mathrm{Br}}$, and bromate yield $\left(\Delta \mathrm{BrO}_{3}{ }^{-}\right.$vs $\Delta \mathrm{HOBr}$, i.e., one-third of slopes in Figure S3B, SI) is depicted in Figure 4. The rate for $\mathrm{HOBr}$ decay to oxygen $\left(k_{\mathrm{BrO}}\right)$ increases with increasing $\mathrm{pH}$, suggesting that an interaction between two $\mathrm{OBr}^{-}$might be important. The $\mathrm{pH}$-dependency of $k_{\mathrm{BrO}}$ follows the opposite trend compared to $k_{\mathrm{ClO}}$ (Figures 2 and 4 ). The reason for this observation remains unknown currently. Similar to $k_{\mathrm{ClP}}$, the maximum $k_{\mathrm{BrP}}$ was obtained near $\mathrm{pH}$ 8.6, approaching the $\mathrm{p} K_{\mathrm{a}}$ of $\mathrm{HOBr}$. This may indicate that the disproportionation occurs between $\mathrm{HOBr}$ and $\mathrm{OBr}^{-}$. The curve for bromate yield follows the same trend as 


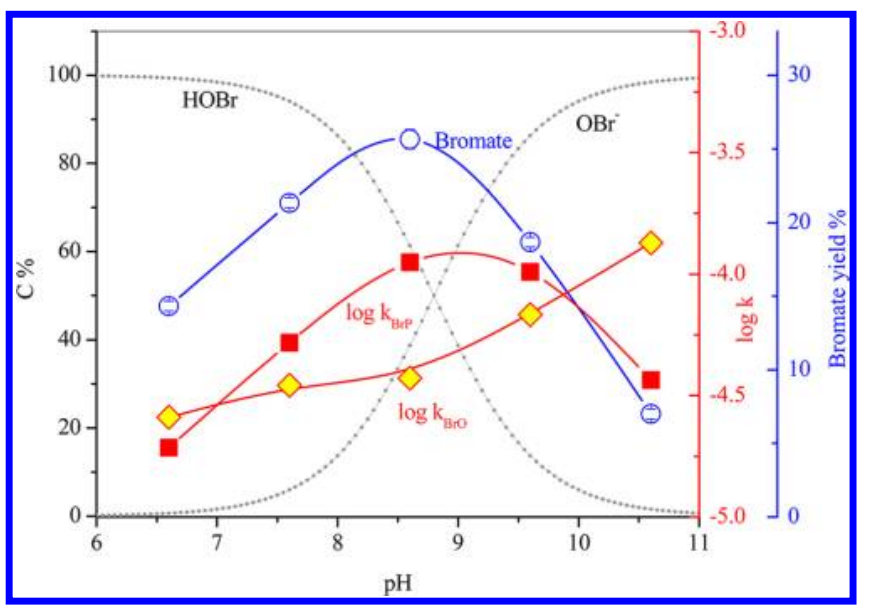

Figure 4. Influence of $\mathrm{pH}$ on speciation of $\mathrm{HOBr}$, rate constants for oxygen formation $\left(k_{\mathrm{BrO}}\right)$ and disproportionation $\left(k_{\mathrm{BrP}}\right)$, and bromate yield. Experimental conditions: $T=21{ }^{\circ} \mathrm{C},[\mathrm{CuO}]=0.2 \mathrm{~g} \mathrm{~L}^{-1}$, $[\mathrm{HOBr}]_{\mathrm{To}}=35 \mu \mathrm{M}$. Reaction times are $180 \mathrm{~min}$.

$k_{\mathrm{BrP}}$. Maximum bromate formation is at the $\mathrm{pH}$ near its $\mathrm{p} K_{\mathrm{a}}$. Again, our data do not reveal which $\mathrm{CuO}$ species mainly contributes to the $\mathrm{HOBr}$ disproportionation.

To better understand the multiple step reactions leading to bromate formation, a conceptual kinetic model was proposed to fit the experimental data (Model 1, SI). It should be noted that in this model only $\mathrm{CuO}$ present in large excess is considered (i.e., the variation of the $\mathrm{CuO}$ species distribution with $\mathrm{pH}$ was not taken into account). The model simulation that agrees well with the experimental trend includes a pre-equilibrium step with the formation of a complex between $\mathrm{HOBr} / \mathrm{OBr}^{-}$and $\mathrm{CuO}$. This initial phase is considered to be the rate-limiting step of the overall catalytic reaction. In the proposed model the disproportionation reaction involving a $\mathrm{CuO}-\mathrm{OBr}^{-}$complex and $\mathrm{HOBr}$ is the predominant reaction pathway (i.e., the reaction rate is 2 orders of magnitude higher than the one estimated for a $\mathrm{CuO}-\mathrm{HOBr}$ complex). Therefore, the $\mathrm{CuO}-$ $\mathrm{HOBr}$ complex seems to play an important role only at $\mathrm{pH} \leq$ 7.6 because $\mathrm{HOBr}$ is the dominant species (>94\%). Furthermore, this model confirms that the disproportionation reaction mainly occurs between two $\mathrm{HOBr}$ and one $\mathrm{OBr}^{-}$, whereas oxygen formation is induced by the interaction between two $\mathrm{OBr}^{-}$. With this model, the experimentally observed pseudo-first-order decay of $\mathrm{HOBr}$ and the trend of bromate formation as a function of the $\mathrm{pH}$ could be reproduced (Model 1, SI).

Bromate Formation during Chlorination of BromideContaining Waters in the Presence of CuO. Results presented above demonstrated that chlorate and bromate can be formed from the catalytic disproportionation of $\mathrm{HOCl}$ and $\mathrm{HOBr}$, respectively. In the following section, bromate formation was investigated using more realistic drinking water treatment conditions, by chlorination of solutions containing bromide and $\mathrm{CuO}$ particles.

1. Effect of CuO Dose. Figure S4 (SI) depicts oxidant decay and bromate formation for various $\mathrm{CuO}$ doses. In the absence of $\mathrm{CuO}$, only a slight oxidant decay was observed, in agreement with previous studies. ${ }^{11,14}$ In the presence of $\mathrm{CuO}$, the oxidant decay was significantly enhanced. Applying pseudo-first-order kinetics to fit the residual oxidant decay rate, one can observe that an increase of the $\mathrm{CuO}$ dose from 0.05 to $0.5 \mathrm{~g} \mathrm{~L}^{-1}$ led to an enhancement of pseudo-first-order rate constants $\left(k^{\prime}\right)$ from $(4.4 \pm 0.3) \times 10^{-5} \mathrm{~s}^{-1}$ to $(3.3 \pm 0.2) \times 10^{-4} \mathrm{~s}^{-1}$ (Table S1, SI)

In the absence of $\mathrm{CuO}$, no significant bromate was formed, in agreement with the data shown above (Figure S4C, SI). In the presence of $\mathrm{CuO}$, a significant bromate formation was observed and enhanced with increasing $\mathrm{CuO}$ dose. For a $\mathrm{CuO}$ dose of $0.5 \mathrm{~g} \mathrm{~L}^{-1}$, the production of bromate reached a plateau after 90 min, showing a bromate yield of $(90 \pm 1) \%$, while for a $\mathrm{CuO}$ dose of $0.2 \mathrm{~g} \mathrm{~L}^{-1}$, the bromate concentration reached a plateau (a bromate yield of $(86 \pm 2) \%$ ) after $150 \mathrm{~min}$. For a $0.05 \mathrm{~g} \mathrm{~L}^{-1}$ $\mathrm{CuO}$ dose, only $(54 \pm 6) \%$ of bromide was converted to bromate after $180 \mathrm{~min}$, but no plateau was reached. Considering the higher bromate yield obtained in the presence of excess chlorine (approaching 100\%), bromate becomes the major sink for bromide. Compared to the lower formation yield in the disproportionation of $\mathrm{HOBr}$ in the absence of $\mathrm{HOCl}$, bromate formation is enhanced because when $\mathrm{HOBr}$ decays to $\mathrm{Br}^{-}$according to eqs 11 and $12 \mathrm{HOCl}$ can regenerate $\mathrm{HOBr}$ from $\mathrm{Br}^{-} \cdot{ }^{14}$ This reaction occurs until $\mathrm{Br}^{-}$is completely transformed to bromate. The difference between the theoretical bromate yield of $100 \%$ and the observed $90 \%$ in Figure S4C (SI) is within the experimental error.

Table S2 (SI) shows that dissolved concentrations of copper are extremely low $\left(20-30 \mathrm{ng} \mathrm{L}^{-1}\right)$ and stable during the entire reaction period, indicating that there is no copper release from the $\mathrm{CuO}$ particles. This confirms that the production of bromate is dominated by heterogeneous reactions.

2. Effect of Initial Concentrations of Chlorine and Bromide. The effects of initial chlorine and bromide concentrations on bromate formation in the presence of $\mathrm{CuO}$ are shown in Figure 5. Figure S5 (SI) shows the corresponding oxidant decay for all applied initial chlorine doses. Applying pseudo-first-order kinetics to interpret the oxidant decay curves gives $k^{\prime}$ values decreasing from $(2.3 \pm 0.1) \times 10^{-4} \mathrm{~s}^{-1}$ to $(1.2 \pm$ $0.1) \times 10^{-4} \mathrm{~s}^{-1}$ for an increase of the initial chlorine concentration from 14 to $70 \mu \mathrm{M}$ (Table S1, SI).

A lag phase can be observed for bromate formation, which is due to the $\mathrm{HOCl}$-dependent $\mathrm{HOBr}$ formation. If the selfdecomposition of $\mathrm{HOCl}$ is neglected and an initial bromide concentration of $10 \mu \mathrm{M}$ is assumed, one can calculate the required times for $90 \%$ bromide oxidation to $\mathrm{HOBr}$ to be 2426 , 1000,600 , and $284 \mathrm{~s}$ for initial chlorine concentrations of 14 , 25,37 , and $70 \mu \mathrm{M}$, respectively. Moreover, considering the selfdecomposition of $\mathrm{HOCl}$ in the presence of $\mathrm{CuO}$, these required times will be longer and lead to a lag phase in bromate formation. Furthermore, the bromate yields reached $(3 \pm 2) \%$, $(18 \pm 6) \%,(64 \pm 1) \%$, and $(86 \pm 2) \%$, after $180 \mathrm{~min}$ with increasing initial chlorine concentrations of $14,25,37$, and 70 $\mu \mathrm{M}$, respectively (Figure $5 \mathrm{~A}$ ). Decreasing the initial $\mathrm{HOCl}$ concentrations significantly decreases the bromate yields. This is because there is not enough $\mathrm{HOCl}$ to oxidize $\mathrm{Br}^{-}$to $\mathrm{HOBr}$ at a lower $\mathrm{HOCl}$ concentration due to the $\mathrm{HOCl}$ consumption through self-decay. For example, if the fast $\mathrm{HOCl}$ self-decay is not considered, one can calculate that at least $30 \mu \mathrm{M} \mathrm{HOCl}$ is needed to convert $10 \mu \mathrm{M} \mathrm{Br}^{-}$to bromate. However, the $\mathrm{HOCl}$ self-decay is very significant, i.e., $70 \%$ consumption within 180 min (Figure 1A). Therefore, the bromate yield for an initial $\mathrm{HOCl}$ concentration of $37 \mu \mathrm{M}$ is smaller than for $70 \mu \mathrm{M}$.

The effect of bromide concentrations on bromate formation was also investigated (Figure 5B). Figure S6 (SI) shows that the corresponding oxidant decay rate constants $k^{\prime}$ increased only slightly (i.e., $(4.5 \pm 0.3) \times 10^{-5} \mathrm{~s}^{-1}$ to $\left.(6.3 \pm 0.3) \times 10^{-5} \mathrm{~s}^{-1}\right)$ with increasing bromide concentration from 2 to $10 \mu \mathrm{M}$ (i.e., 


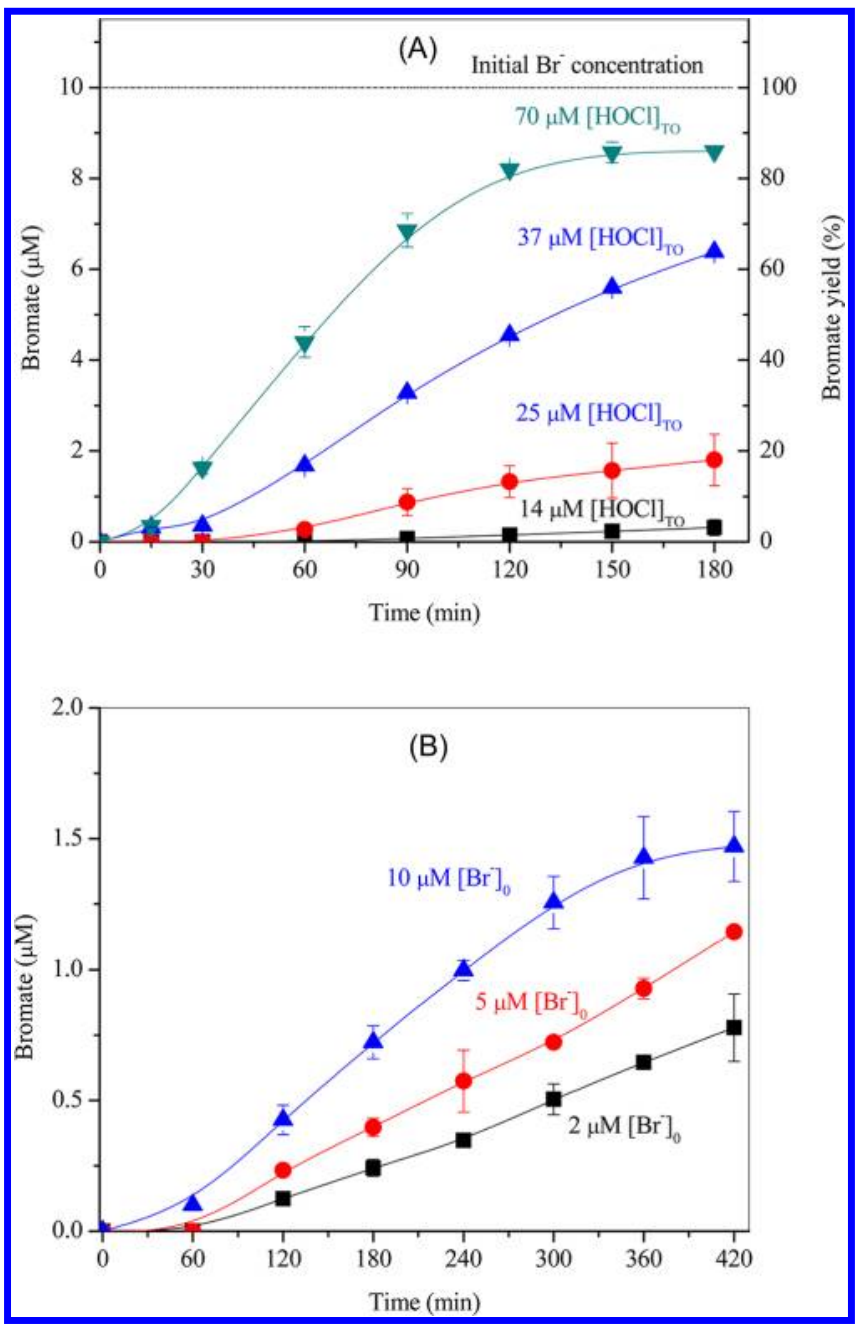

Figure 5. Effects of initial concentrations of (A) $\mathrm{HOCl}$ and (B) bromide on bromate formation. Experimental conditions: $\mathrm{pH}=8.6$ (2.5 mM tetraborate buffer), $T=21^{\circ} \mathrm{C}$. (A) $\left[\mathrm{Br}^{-}\right]_{\mathrm{o}}=10 \mu \mathrm{M},[\mathrm{CuO}]$ $=0.2 \mathrm{~g} \mathrm{~L}^{-1}$; (B) $[\mathrm{HOCl}]_{\mathrm{To}}=15 \mu \mathrm{M}\left(1.1 \mathrm{mg} \mathrm{L}^{-1} \mathrm{Cl}_{2}\right),[\mathrm{CuO}]=0.05 \mathrm{~g}$ $\mathrm{L}^{-1}$.

160-800 $\mu \mathrm{g} \mathrm{L}^{-1}$ ) (Table S1, SI). In contrast, an enhanced bromate formation was observed for an increase in the initial bromide concentration (Figure $5 \mathrm{~B}$ ). After a reaction time of $420 \mathrm{~min}$, the resulting bromate concentrations were $0.8 \pm 0.1$, $1.1 \pm 0.1$, and $1.5 \pm 0.1 \mu \mathrm{M}$, corresponding to bromate yields of $(40 \pm 5) \%,(22 \pm 2) \%$, and $(15 \pm 1) \%$ for initial bromide levels of 2, 5, and $10 \mu \mathrm{M}$, respectively, and a $\mathrm{HOCl}$ dose of 15 $\mu \mathrm{M}\left(1.1 \mathrm{mg} \mathrm{L}^{-1} \mathrm{Cl}_{2}\right)$. Increasing bromide concentration led to higher bromate concentrations because of the higher steadystate concentrations of $\mathrm{HOBr}$. However, the bromate yield highly depends on the $\mathrm{HOCl} / \mathrm{Br}^{-}$ratio. For high ratios (low initial $\mathrm{Br}^{-}$concentration), the recycling of $\mathrm{Br}^{-}$produced by eqs 11 and 12 is effective. However, when the $\mathrm{HOCl} / \mathrm{Br}^{-}$ratio approaches 1 , the maximum $\mathrm{BrO}_{3}{ }^{-}$concentration corresponds to the lower yield of the pure $\mathrm{HOBr}$ system.

3. Effect of $\mathrm{pH}$. During the chlorination of bromidecontaining waters in the presence of $\mathrm{CuO}$, both oxidant decay and bromate formation are significantly affected by $\mathrm{pH}$ in the range of 6.6-9.6, overlapping with drinking water conditions (Figure 6). Oxidant decay follows pseudo-first-order kinetics (Figure S7, SI). The decay rate constants increase with decreasing $\mathrm{pH}$ from 9.6 to 6.6 , corresponding to $k^{\prime}$ values

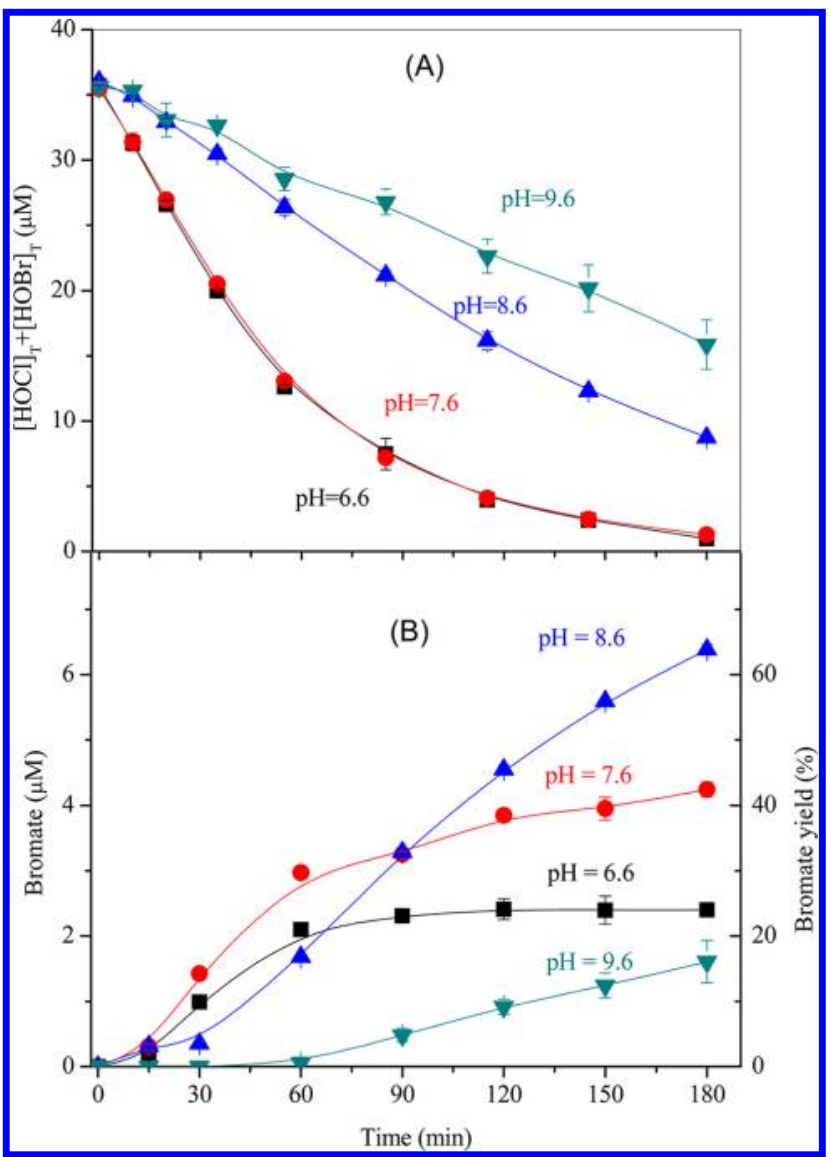

Figure 6. Effect of $\mathrm{pH}$ on (A) oxidant decay and (B) bromate formation. Experimental conditions: $T=21{ }^{\circ} \mathrm{C},\left[\mathrm{Br}^{-}\right]_{\mathrm{o}}=10 \mu \mathrm{M}$, $[\mathrm{CuO}]=0.2 \mathrm{~g} \mathrm{~L}^{-1},[\mathrm{HOCl}]_{\mathrm{To}}=37 \mu \mathrm{M}\left(2.6 \mathrm{mg} \mathrm{L}^{-1} \mathrm{Cl}_{2}\right)$.

ranging from $(6.8 \pm 0.5) \times 10^{-5} \mathrm{~s}^{-1}$ to $(3.2 \pm 0.1) \times 10^{-4} \mathrm{~s}^{-1}$ (Table S1, SI). This trend is similar to the $\mathrm{HOCl}-\mathrm{CuO}$ system (Figure 1) but opposite to the observed trend for the $\mathrm{HOBr}-$ $\mathrm{CuO}$ system (Figure 3). This is because in the $\mathrm{HOCl}-\mathrm{Br}^{-}-$ $\mathrm{CuO}$ system the reaction is initiated by $\mathrm{HOCl}$, and $\mathrm{HOCl}$ is present in large excess of $\mathrm{Br}^{-}$; namely, $\mathrm{HOBr}\left([\mathrm{HOCl}]_{\mathrm{o}}=37\right.$ $\mu \mathrm{M}$ and $\left.\left[\mathrm{Br}^{-}\right]_{\mathrm{o}}=10 \mu \mathrm{M}\right)$.

Bromate formation shows a complex pattern (Figure 6B). During the first $60 \mathrm{~min}$ of reaction, maximum bromate formation was observed at $\mathrm{pH} 7.6$, followed by $\mathrm{pH} 6.6$ and 8.6. At $\mathrm{pH} 9.6$ the formation of bromate is insignificant (less than $0.2 \mu \mathrm{M})$. Using initial concentrations of 37 and $10 \mu \mathrm{M}$ for chlorine and bromide, respectively, one can calculate the reaction times for $90 \%$ bromide oxidation to $\mathrm{HOBr}$. At $\mathrm{pHs} 6.6$ and 7.6, bromide is quickly converted into $\mathrm{HOBr}$ within $1-2$ min, while at higher $\mathrm{pH}$ (i.e., 8.6 and 9.6), >10 min is needed to oxidize $90 \%$ of the initial bromide to $\mathrm{HOBr}$. Therefore, due to the significant production of $\mathrm{HOBr}$, the formation of bromate is favored at lower $\mathrm{pH}$ during the early stage of the reaction. The bromate concentration at $\mathrm{pH} 7.6$ is higher than that at 6.6 owing to the enhanced $k_{\mathrm{BrP}}$ rate (Figure 4 ).

After $60 \mathrm{~min}$, the remaining oxidant concentration becomes low for $\mathrm{pH} 6.6$ and 7.6 (only about $33 \%$ of the initial oxidant remaining) because $k_{\mathrm{ClO}}$ is higher at lower $\mathrm{pH}$ values. Consequently, only a slow increase of bromate was observed during this phase. Due to the formation of a significant amount of $\mathrm{HOBr}$, bromate further increases at $\mathrm{pHs} 8.6$ and 9.6. At 180 min, about $(24 \pm 2) \%,(43 \pm 1) \%,(64 \pm 1) \%$, and $(16 \pm 3) \%$ of the initial bromide was converted to bromate for $\mathrm{pH} 6.6,7.6$, 
8.6, and 9.6, respectively. The higher yield in the $\mathrm{HOCl}-\mathrm{Br}^{-}$ experiment compared to $\mathrm{HOBr}$ alone is due to the recycling of $\mathrm{Br}^{-}$to $\mathrm{HOBr}$ by $\mathrm{HOCl}$.

Bromate Formation Mechanism during Chlorination of Bromide-Containing Waters in the Presence of $\mathrm{CuO}$. According to our data, a hypothetical bromate formation mechanism during chlorination of bromide-containing waters in the presence of $\mathrm{CuO}$ can be postulated (Scheme 1). Bromate

Scheme 1. Potential Reactions during Chlorination of Bromide-Containing Waters in the Presence of $\mathrm{CuO}^{a}$

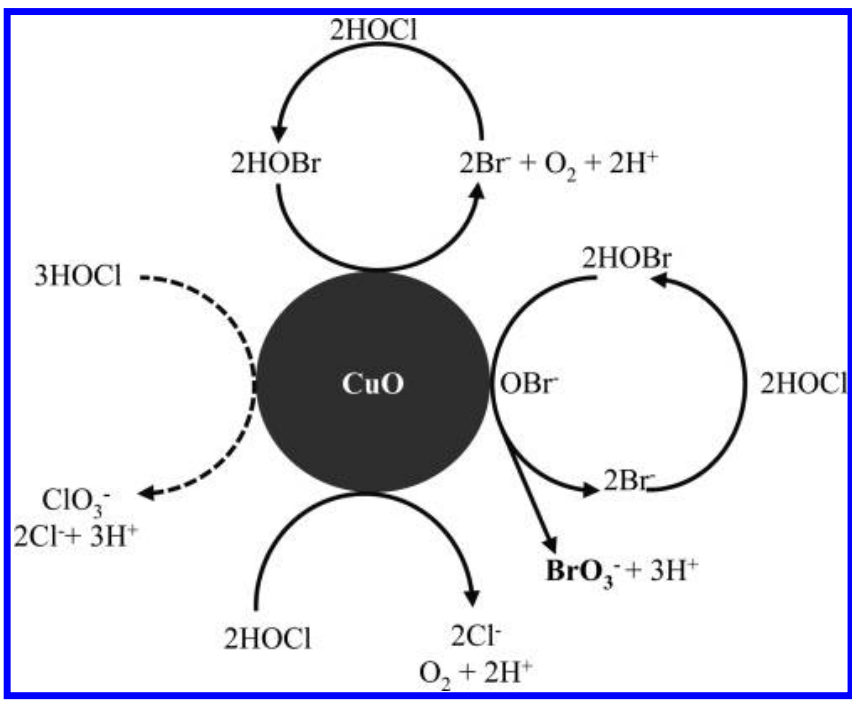

${ }^{a}$ Solid lines, main pathways; dashed lines, minor pathways.

formation is initiated by the oxidation of bromide by $\mathrm{HOCl}$ to $\mathrm{HOBr}$ (eq 1). The reaction between $\mathrm{HOCl}$ and $\mathrm{Br}^{-}$dominates because the reaction rate constant between $\mathrm{OCl}^{-}$and $\mathrm{Br}^{-}$is low (eq 2). ${ }^{13}$

In the presence of $\mathrm{CuO}$, the $\mathrm{HOBr}$ decay rate is significantly enhanced (e.g., $10^{4}$ times with $0.2 \mathrm{~g} \mathrm{~L}^{-1} \mathrm{CuO}$ at $\mathrm{pH} 8.6$ ), via two reaction pathways (eqs 11 and 12). For $\mathrm{pH}$ between 7.6 and 9.6, the disproportionation of $\mathrm{HOBr}$ to bromate is the major pathway, and the reaction rate is highest near the $\mathrm{p} K_{\mathrm{a}}$ of $\mathrm{HOBr}$. Therefore, the reaction occurs between $\mathrm{HOBr}$ and $\mathrm{OBr}^{-}$.

$\mathrm{CuO}$ is a catalyst for $\mathrm{HOBr}$ disproportionation, and the catalysis has to be initiated by the adsorption of $\mathrm{HOBr} / \mathrm{OBr}^{-}$ on the $\mathrm{CuO}$ surface. Because $\mathrm{HOBr} / \mathrm{OBr}^{-}$is not stable on the $\mathrm{CuO}$ surface, the adsorption of $\mathrm{HOBr} / \mathrm{OBr}^{-}$by $\mathrm{CuO}$ is difficult to be confirmed. However, the presence of phosphate $(1 \mathrm{mM})$ strongly inhibits bromate formation (about $80 \%$ inhibition) in a reaction system containing $\mathrm{HOCl}, \mathrm{Br}^{-}$, and $\mathrm{CuO} .{ }^{17}$ Therefore, it is hypothesized that $\mathrm{HOBr} / \mathrm{OBr}^{-}$can be adsorbed on the $\mathrm{CuO}$ surface and forms complexes.

It was reported that copper can catalyze the formation of chlorination byproducts (e.g., chloroform, ${ }^{29}$ haloacetic acids ${ }^{30}$ ). Iodine species adsorbed on $\delta$ - $\mathrm{MnO}_{2}$ can also contribute to the formation of iodinated organic compounds. ${ }^{31} \mathrm{By}$ analogy, we hypothesized that complexation of $\mathrm{HOBr} / \mathrm{OBr}^{-}$by the Lewis acid $\mathrm{CuO}$ polarizes the bromine molecule, thus increasing its electrophilicity and as a consequence its reactivity. The $\mathrm{CuO}-$ bromine complex reacts with $\mathrm{HOBr}$ to form $\mathrm{BrO}_{2}^{-}$. According to our conceptual model (Model 1, SI), the reaction between the $\mathrm{CuO}-\mathrm{OBr}^{-}$complex and $\mathrm{HOBr}$ is the predominant reaction pathway (i.e., the reaction rate constant is 2 orders of magnitude higher than the one estimated for the $\mathrm{CuO}-\mathrm{HOBr}$ complex). The latter reaction tends to be important only at lower $\mathrm{pH}$ for which $\mathrm{HOBr}$ is the predominant species.

The second-order rate constant for the reaction between $\mathrm{HOCl}$ and $\mathrm{BrO}_{2}^{-}$is $160 \mathrm{M}^{-1} \mathrm{~s}^{-1}$ in homogeneous solution, and the primary product (about $85 \%$ ) is $\mathrm{ClO}_{3}^{-32}$ The production of chlorite and chlorate is insignificant during $\mathrm{HOCl}-\mathrm{Br}^{-}$ reactions in the presence of $\mathrm{CuO}$ (less than $0.02 \mu \mathrm{M}$, Table S1, SI). This indicates that chlorate formation is a minor pathway. Therefore, it is proposed that bromate is formed by a successive oxidation of $\mathrm{BrO}_{2}^{-}$by $\mathrm{HOBr}$ which is catalyzed by $\mathrm{CuO}$ and not by the reaction between $\mathrm{HOCl}$ and $\mathrm{BrO}_{2}^{-}$. The consumption of $\mathrm{HOCl}$ is mainly via (1) oxidation of $\mathrm{Br}^{-}$and (2) self-decay to oxygen.

Bromide which results from these reactions is oxidized by $\mathrm{HOCl}$ to $\mathrm{HOBr}$, which further disproportionates to $\mathrm{BrO}_{3}^{-}$and $\mathrm{Br}^{-}$until most of the bromide is converted to bromate as long as $\mathrm{HOCl}$ is present in excess.

The generation of $\mathrm{O}_{2}$ (eqs 9 and 12) is an important side reaction for $\mathrm{HOCl}$ or $\mathrm{HOBr}$ decay. For $\mathrm{pH}$ values below 7.6 or above 9.6, this reaction becomes more significant. The $\mathrm{O}_{2}$ formation is initiated by the oxidation of $\mathrm{Cu}(\mathrm{II})$ by $\mathrm{HOCl}$ or $\mathrm{HOBr}$ to form dimeric $\mathrm{Cu}(\mathrm{III})$ intermediates, and then this dimeric $\mathrm{Cu}$ (III) decays to give rise to $\mathrm{Cu}$ (II) and $\mathrm{O}_{2}{ }^{19,21}$ The $\mathrm{O}_{2}$ generation does not affect the bromate yield in the $\mathrm{HOCl}-$ $\mathrm{Br}^{-}$system in excess of $\mathrm{HOCl}$ because of a recycling of $\mathrm{Br}^{-}$to $\mathrm{HOBr}$.

Implications for Water Treatment. Traditionally only oxygen and halide ions were considered as the products from catalyzed hypohalite decomposition in the presence of metal oxides (e.g., $\mathrm{CuO}){ }^{18,19,21,22}$ This leads to an enhanced oxidant decay in distribution systems containing corrosion products. $^{23,30}$ From a drinking water quality point of view, a partial loss of disinfectants is problematic, and an enhanced formation of disinfection byproduct makes this even worse. This study shows that $\mathrm{CuO}$ catalyzes the disproportionation of $\mathrm{HOCl}$ and $\mathrm{HOBr}$ leading to significant formation of chlorate and bromate, respectively. It is known that $\mathrm{CuO}$ is one of the main forms of copper corrosion. ${ }^{20,33}$ This may be a major concern for the drinking water quality in distribution systems containing copper pipes, which are widely used worldwide in municipal and household systems.

Drinking water regulations for bromate are stricter than those for chlorate (WHO guidelines: $10 \mu \mathrm{g} \mathrm{L}^{-1}$ for bromate and $700 \mu \mathrm{g} \mathrm{L}^{-1}$ for chlorate (provisional) ${ }^{8}$ ). Bromide levels in raw waters (e.g., groundwaters, surface waters, and desalinated waters) are highly variable in a range of $10-1000 \mu \mathrm{g} \mathrm{L}^{-1} .9$ The average bromide concentration within natural waters in the United States is almost $100 \mu \mathrm{g} \mathrm{L}^{-1} \cdot{ }^{34}$ Moreover, due to the high bromate yield in the $\mathrm{HOCl}-\mathrm{Br}^{-}-\mathrm{CuO}$ systems, one can expect that the regulation for bromate would not be met for a $10 \%$ bromate yield (or higher yields which were found in Figure 5B) if the bromide concentration is above $80 \mu \mathrm{g} \mathrm{L} \mathrm{L}^{-1}$. This hypothesis is based on laboratory experiments in clean waters without taking the water matrix of real drinking waters into consideration (mainly concentration and type of dissolved organic matter (DOM)). It is expected that the adsorption of $\mathrm{DOM}$ on $\mathrm{CuO}$ will reduce the catalytic activity of $\mathrm{CuO}$ for bromate formation. Moreover, $\mathrm{HOBr}$ may react with $\mathrm{DOM}$ leading to bromo-organic compounds, thereby diminishing bromate formation. However, the issue of bromate formation during chlorination should still be considered seriously when copper pipes are used. 
On the basis of our results, bromate minimization for distribution systems using chlorination can be achieved by (1) replacement of copper pipes; (2) lowering the residual chlorine concentration if disinfection can still be guaranteed; and (3) $\mathrm{pH}$ adjustment to $<7.6$ if corrosion is not enhanced. Moreover, bromate could be minimized using alternative disinfectants (e.g., chlorine dioxide or chloramine which both have low rate constants for oxidation of $\mathrm{Br}^{-}$to $\mathrm{HOBr}^{35,36}$ ). Additional research should address the effects of DOM on the formation of bromate and bromo-organic byproduct during chlorination of bromide-containing waters in the presence of $\mathrm{CuO}$.

\section{ASSOCIATED CONTENT}

\section{S Supporting Information}

Additional details of the Materials and Methods, additional figures, and kinetic modeling. This material is available free of charge via the Internet at http://pubs.acs.org.

\section{AUTHOR INFORMATION}

\section{Corresponding Author}

*Tel.: +996-2-8082984. E-mail: jp.croue@kaust.edu.sa.

\section{Notes}

The authors declare no competing financial interest.

\section{ACKNOWLEDGMENTS}

The authors would like to thank Ms. Tong Zhan for ICP-MS analyses.

\section{REFERENCES}

(1) Haag, W. R.; Hoigné, J. Ozonation of bromide-containing waters: kinetics of formation of hypobromous acid and bromate. Environ. Sci. Technol. 1983, 17, 261-267.

(2) von Gunten, U.; Hoigné, J. Bromate formation during ozonation of bromide-containing waters: Interaction of ozone and hydroxyl radical reactions. Environ. Sci. Technol. 1994, 28, 1234-1242.

(3) Croué, J. P.; Kodjonou, B. K.; Legube, B. Parameters affecting the formation of bromate ion during ozonation. Ozone Sci. Eng. 1996, 18, $1-18$.

(4) von Gunten, U.; Oliveras, Y. Kinetics of the reaction between hydrogen peroxide and hypobromous acid: implication on water treatment and natural systems. Water Res. 1997, 31, 900-906.

(5) von Gunten, U.; Oliveras, Y. Advanced oxidation of bromidecontaining waters: bromate formation mechanisms. Environ. Sci. Technol. 1998, 32, 63-70.

(6) European Communities, European Communities (Drinking water) (No.2) Regulations. In Brussels, 2007.

(7) U.S. Environmental Protection Agency, National Primary Drinking Water Regulations. In Washington D.C., 2001.

(8) World Health Organization, Guidelines for Drinking-water Quality. In Geneva, 2008.

(9) von Gunten, U. Ozonation of drinkingwater: part II. disinfection and by-product formation in presence of bromide, iodide or chlorine. Water Res. 2003, 37, 1469-1487.

(10) Weinberg, H.; Delcomyn, C.; Unnam, V. Bromate in chlorinated drinking waters: Occurrence and implications for future regulation. Environ. Sci. Technol. 2003, 37 (14), 3104-3110.

(11) Huang, X.; Gao, N.; Deng, Y. Bromate ion formation in dark chlorination and ultraviolet/chlorination processes for bromidecontaining water. J. Environ. Sci. 2008, 20, 246-251.

(12) Macalady, D. L.; Carpenter, J. H.; Moore, C. A. Sunlight induced bromate formation in chlorinated seawater. Science 1977, 195 (4284), 1335-1337.

(13) Kumar, K.; Margerum, D. W. Kinetics and mechanism of general- acid-assisted oxidation of bromide by hypochlorite and hypochlorous acid. Inorg. Chem. 1987, 26 (16), 2706-2711.
(14) Margerum, D. W.; Huff Hartz, K. E. Role of halogen(I) cationtransfer mechanisms in water chlorination in the presence of bromide ion. J. Environ. Monit. 2002, 4, 20-26.

(15) Beckwith, R. C.; Margerum, D. W. Kinetics of hypobromous acid disproportionation. Inorg. Chem. 1997, 36, 3754-3760.

(16) Engel, P.; Oplatka, A.; Perlmutter-Hayman, B. The decomposition of hypobromite and bromite solutions. J. Am. Chem. Soc. 1954, 76, 2010-2015.

(17) Liu, C.; Croué, J. P. Metal oxides enhanced bromate formation during chlorination of bromide-containing waters in distribution systems. In preparation.

(18) Lewis, J. R. The catalytic decomposition of sodium hypochlorite solutions. J. Phys. Chem. 1928, 32, 1808-1819.

(19) Lister, M. W. Decomposition of sodium hypochlorite: The catalyzed reaction. Can. J. Chem. 1956, 34, 479-488.

(20) Li, B.; Qu, J.; Liu, H.; Hu, C. Effects of copper(II) and copper oxides on THMs formation in copper pipe. Chemosphere 2007, 68, 2153-2160.

(21) Gray, E. T.; Taylor, R. W.; Margerum, D. W. Kinetics and mechanisms of the copper-catalyzed decomposition of hypochlorite and hypobromite. Properties of a dimeric copper (III) hydroxide intermediate. Inorg. Chem. 1977, 16, 3047-3055.

(22) Church, J. A. Kinetics of the uncatalyzed and $\mathrm{Cu}$ (II) -catalyzed decomposition of sodium hypochlorite. Ind. Eng. Chem. Res. 1994, 33, 239-245.

(23) Nguyen, C. K.; Powers, K. A.; Raetz, M. A.; Parks, J. L.; Edwards, M. A. Rapid free chlorine decay in the presence of $\mathrm{Cu}(\mathrm{OH})_{2}$ : Chemistry and practical implications. Water Res. 2011, 45, 5302-5312.

(24) Lei, H.; Marinas, B. J.; Minear, R. A. Bromamine decomposition kinetics in aqueous solutions. Environ. Sci. Technol. 2004, 38 (7), 2111-2119.

(25) Stumm, W. Chemistry of the Solid-Water Interface; JohnWiley and Sons: New York. 1992.

(26) American Public Health Association (APHA). Standard Methods for the Examination of Water and Wastewater. APHA, American Water Works Association, and Water Environment Federation, Washington, D.C., 1998.

(27) Adam, L. C.; Fabian, I.; Suzuki, K.; Gordon, G. Hypochlorous acid decomposition in the $\mathrm{pH} 5-8$ region. Inorg. Chem. 1992, 31, $3534-3541$

(28) Adam, L. C.; Gordon, G. Hypochlorite ion decomposition: Effects of temperature, ionic Strength, and chloride Ion. Inorg. Chem. 1999, 38, 1299-1304.

(29) Blatchley, E. R.; Margetas, D.; Duggirala, R. Copper catalysis in chloroform formation during water chlorination. Water Res. 2003, 37 (18), 4385-4394.

(30) Zhang, H.; Andrews, S. A. Catalysis of copper corrosion products on chlorine decay and HAA formation in simulated distribution systems. Water Res. 2012, 46, 2665-2673.

(31) Gallard, H.; Allard, S.; Nicolau, R.; von Gunten, U.; Croué, J. P. Formation of iodinated organic compounds by oxidation of iodidecontaining waters with manganese dioxide. Environ. Sci. Technol. 2009, 43, 7003-7009.

(32) Nicoson, J. S.; Perrone, T. F.; Huff Hartz, K. E.; Wang, L.; Margerum, D. W. Kinetics and mechanisms of the reactions of hypochlorous acid, chlorine, and chlorine monoxide with bromite ion. Inorg. Chem. 2003, 42, 5818-5824.

(33) Shim, J. J.; Kim, J. G. Copper corrosion in potable water distribution systems: influence of copper products on the corrosion behavior. Mater. Lett. 2004, 58, 2002-2006.

(34) Amy, G.; Siddiqui, M.; Zhai, W.; Debroux, J. National survey of bromide in drinking waters. Proc. of AWWA Annual Conference. Denver, Colo: AWWA ,1993.

(35) Hoigné, J.; Bader, H. Kinetics of reactions of chlorine dioxide $(\mathrm{OClO})$ in water - I. Rate constants for inorganic and organic compounds. Water Res. 1994, 28 (1), 45-55.

(36) Trofe, T. W.; Inman, G. W.; Johnson, J. D. Kinetics of monochloramine decomposition in the presence of bromide. Environ. Sci. Technol. 1980, 14 (5), 544-549. 